ENTREPRENEURSHIP AND SUSTAINABILITY ISSUES

ISSN 2345-0282 (online) http://jssidoi.org/jesi/

2020 Volume 7 Number 3 (March)

http://doi.org/10.9770/jesi.2020.7.3(28)

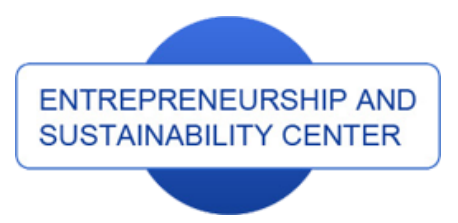

Publisher

http://jssidoi.org/esc/home

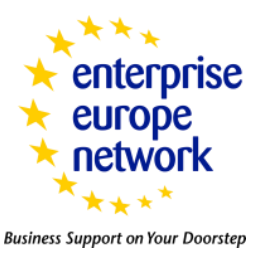

CASPA

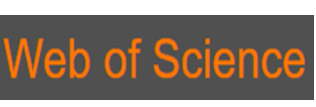

1) Clarivate

\title{
A DIAMOND MODEL BASED ANALYSIS FOR IMPROVING THE SUSTAINABLE COMPETITIVENESS IN EDUCATIONAL EXPORTS BY CHINESE COLLEGES AND UNIVERSITIES ${ }^{*}$
}

\author{
Yingfei Yang ${ }^{1}$, Michal Fabus ${ }^{2}$, Ki-Hyung Bae ${ }^{3}$, Mengze Zhang ${ }^{4}$ \\ ${ }^{1}$ Sejong University, 209, Neungdong-ro, Gwangjin-gu, Seoul, South Korea \\ ${ }^{I}$ Ningbo University of Finance \& Economics, No. 899, Xueyuan Rd, Haishu District, Ningbo, Zhejiang, \\ People's Republic of China \\ ${ }^{2}$ School of Economics and Management in Public Administration in Bratislava, Furdekova 16, 85104 Bratislava, \\ Slovak Republic \\ ${ }^{3,4}$ Sejong University, 209, Neungdong-ro, Gwangjin-gu, Seoul, South Korea \\ E-mails: ${ }^{1}$ yangyingfei@nbufe.edu.cn $;{ }^{2}$ michal.fabus@vsemvs.sk; ${ }^{3}$ baekh@sejong.ac.kr; ${ }^{4}$ allen.mengze@foxmail.com
}

Received 15 August 2019; accepted 25 November 2019; published 30 March 2020

\begin{abstract}
Nowadays, as one of the most important part of international trade, Service trade also affects the economic development of each country in the world. Although China's Educational exports have increased year by year, there are still trade deficits due to some reason. This paper mainly focuses on the local colleges and universities, and analyse the factors affecting the international sustainable competitiveness of the education exports of these institutions, based on Porter's national diamond model. And Finally, It put forward an effective way to enhance China's international sustainable competitiveness in the educational service market.
\end{abstract}

Keywords: Education Exports; National Diamond Model; Sustainable competitiveness; Local Colleges and Universities.

Reference to this paper should be made as follows: Yang, Y., Fabus, M., Bae, K.-H., Zhang, M. 2020. A diamond model based analysis for improving the sustainable competitiveness in educational exports by Chinese colleges and universities, 7(3), 1858-1871. https://doi.org/10.9770/jesi.2020.7.3(28)

JEL Classifications: F14, I23, L89, O53

\section{Introduction}

\subsection{Background and the significance of the research topic}

With the ever-growing trend of globalization in politics, economy, and lifestyles, so is the pattern of exchange of educational resources among countries as the domestic educational market of various countries is gradually

\footnotetext{
* The paper is the output of an international scientific project IGA no. 2/2018 - M „,Problems and Suggestions - Comparison of Commercial Enviroment between China - Slovakia and Facilitation of Trade and Investment". (Funder: VSEMvs IGA VSEMvs, i.e. School of Economics and Management in Public Administration) and scienfitic project code: Y201942732 "Research on the path of increasing the abilities of Higher Education Exports of Zhejiang under Anti-Globalization" (Funder: Education Deparment of Zhejiang, PRC, project classification - General Scientific Research Project)
} 


\section{ENTREPRENEURSHIP AND SUSTAINABILITY ISSUES}

ISSN 2345-0282 (online) http://jssidoi.org/jesi/

2020 Volume 7 Number 3 (March)

http://doi.org/10.9770/jesi.2020.7.3(28)

opening up to the outside world. Education export, as one of the essential components of service trade, can bring great economic benefits to a country, as well as serve as a new growth point to further promote the country's economic development (Girdzijauskaite et al., 2019). In addition, it can enhance a country's political and cultural exposure and influences on the international stage, and act as an important driving force for the cultivation of talents and scientific and technological progress.

At the same time, education exports can also be the necessary stimulant to the education industry itself, promoting the overall level of globalization of education and improving the international sustainable competitiveness of the industry.

Compared with developed countries worldwide, China's education exports are lagging far behind the norm. It has the world's largest trade deficit in education services and is the world's largest importer of education. As a result, its education exports are in a very disadvantageous position in the highly competitive international market. At present, in terms of the composition of China's higher educational institutions, the proportion of local colleges and universities exceeds 90\%. Local colleges and universities have now become the core of national higher education, and the performance of its education exports directly affect the overall level of the international competitiveness of China's education industry. Therefore, research studies on how to strengthen the education export sustainable competitiveness of these local colleges and universities are of great significance. The results would definitely lead to the improvement of China's higher education exports and enhance its international sustainable competitiveness.

\subsection{Innovations and deficiency of research}

In recent years, the internationalization of higher education has become an increasingly difficult issue to deal with, and hence a hot research topic. This paper focused on the field of education export, which is relatively difficult to quantify due to the lack of data, and as a result, its finding has certain innovation in enriching the research in this field.

In addition, this paper adopts the analysis method of econometric model, and incorporates, on the basis of Porter's National Diamond model, new microscopic variables into the empirical model. This approach makes this research framework more three-dimensional and ideal, when compared to the traditional analysis where only macroscopic factors are considered.

However, due to the inherent difficulties involved in the data acquisition and selections on the education exports of the local colleges and universities, there may exist some deficiencies, which may lead to certain deviations of the research findings.

\section{Literature review}

\subsection{Current Domestic Research Status}

In light of China's outstanding education service trade deficit, many domestic scholars have begun to pay attention to the issues concerning the export of higher education and put forward various strategies to enhance the sustainable competitiveness of its education industry in the context of globalization. The efforts mainly focused on the following aspects:

(1) On the theory of sustained competitive advantage.

Zuo Shixiang (2016) believes that changes in core resources, core competencies and the external environment are key factors in determining China's participation in international trade in education services.

(2) On the analysis of competitiveness indicators.

For instance, Wang Feng and He Yixiao (2014) believe that the main indicators embodying the competitiveness of education exports are the Trade Competitiveness Index (TC), the indicative Comparative Advantage Index (RCA) and the indicative Competitive Advantage Index (RC); while Shi Jie (2012) thinks the International Market Share indicator (IMS) plays a crucial role in measuring a country's educational export competitiveness. 


\section{ENTREPRENEURSHIP AND SUSTAINABILITY ISSUES}

ISSN 2345-0282 (online) http://jssidoi.org/jesi/

2020 Volume 7 Number 3 (March)

http://doi.org/10.9770/jesi.2020.7.3(28)

(3) On analysis on factors impacting the competitiveness.

Some scholars conducted studies on the main factors affecting China's education services trade, based on Porter's "National Diamond Theory" (Liu Xin, 2007; Chen Xi, 2015; Jin Niu, 2016). While others mainly relied on quantitative analysis approach to study the main factors affecting the service trade in higher education (Lu Xin, 2013).

(4) On analysis on regional and national competitiveness.

These studies mostly focused on developed countries, ASEAN countries (Sun Weike, 2013), Japan and South Korea (Zhai Guiyong, 2007), and countries along the "Belt and Road Initiative" economic corridors (Wen Sijun \& Qi Liangliang, 2016).

\subsection{Current research status}

(1) On the study of education services trade.

The study of educational service trade by foreign scholars and research institutions can be traced back to Marx's exposition of "education", which is also rich in theoretical research results. The contributions of Adams Smith and David Ricardo to international trade theory are the theoretical cornerstone of all types of trade research (Adam Smith, 2014; David Ricardo, 2014).

Some scholars have carried on the deep interpretation to the education service trade part in the GATS clause and analyzed the effects of GATS to the higher education as well the main role transformation of governments and students (Knight, 2002).

(2) On the study of factors influencing the competitiveness of educational services.

Such as Michael Porter (2008). This paper analyzed the import and export of education in the United States from the cost and benefits perspectives and put forward the core elements that affected the competitiveness level of American education service trade.

Also, the Organization for Economic Co-Development (OECD) (2009), on the basis of analyzing the educational development of OECD member countries and other nations' trade in education services, pointed out that the main factors affecting students' choice of overseas study destinations are language, tuition fees, immigration policies, etc.

\section{Methodology}

\subsection{Theoretical analysis 3.1.1 The definition of concepts}

\section{The basic definition of local colleges and universities}

The local colleges and universities in this study refer to those full-time institutions whose funding sources are primarily local government and private resources, and whose main service target is the local economic development and social progress. This definition includes the ordinary undergraduate colleges and vocational schools. According to list of national colleges and universities published by the Ministry of Education, as of May 31, 2017, China has 2631 national general institutions of higher learning (which include 1243 undergraduate colleges, and 265 independent colleges); of which, there are a total of 195 subordinate colleges and universities (190 undergraduate units, and 5 specialized units).

\section{The definition of education export}

The General Agreement on Trade in Services (GATS), which was enforced in 1995, defines four modes of delivery of trade in services, namely, cross-border delivery, cross-border consumption, commercial presence, and 


\section{ENTREPRENEURSHIP AND SUSTAINABILITY ISSUES}

ISSN 2345-0282 (online) http://jssidoi.org/jesi/

2020 Volume 7 Number 3 (March)

http://doi.org/10.9770/jesi.2020.7.3(28)

movement of natural persons. Of the 12 classifications of trade in services, the 5th category - the trade on education - can be further divided into education exports and education imports. The term "educational export" is interpreted as being engaged in such actions such as a Member State accepting foreign students, or going abroad to manage an institution, either independently of jointly with other entities, for the purpose of acquiring certain economic benefits. At present, China's educational exports concentrated in the area of providing services for international students; other forms of export, such as overseas schools and cross-border distance learning, accounted for a relatively insignificant proportion of the total education export, generally lacked definitive data and information. Therefore, the current study is primarily oriented toward education exports concerning international students. That is, the level of foreign students' acceptance is the main indicator of education exports for the current research.

\section{The definition of the competitiveness of education export}

Competitiveness is generally understood as a competitive ability, relative to a competitor's comparative advantage or strength. At present, there is a rather authoritative viewpoint internationally on the study of competitiveness, presented by Michael E Porter. He believes that "competitiveness is the comprehensive quality of a country or a region in which an industry is able to provide products or services to the market more effectively than similar industries in other countries or regions." The introduction of this concept into trade in education services means that the competitiveness of educational exports can be defined as the ability of trade subjects to engage in educational export activities in various environments in the form of trade provided for in GATS, encompassing both the competitiveness among schools (educational institutions) and that resulting from external environmental influences.

\subsubsection{Porter's National Diamond Theory}

In the eighties and the nineties of the 20th century, Michael Porter, a professor at the Harvard Business School in the United States, combined businesses, industries and countries in his published work "Competitive Trilogy Competition Strategy, Competitive Advantage and National Competitive Advantage." He used the so-called "National Diamond Model" to explain the reasons why certain countries have gained an advantage in the international competition of industry. In his view, the key factors that determine this international competitiveness can be divided into four main categories, namely, production factors, demand conditions, related and support industries performance, and the development strategies. When shown graphically, these four interrelated groups of key factors form a diamond-like shape, hence the term "diamond system."

Porter's national diamond theory mainly analyzes the object of "industry", especially the manufacturing industry. Although higher education has special implications, such as its sociality and non-profit nature, its industrial nature is not obvious. However, with the advancement of globalization and the fact that WTO's General Agreement on Trade in Services (GATS) now formally includes education in the category of "trade in services", and provides for four forms of trade in education services, it is an indisputable fact that trade in education services is real and rapidly developing. Therefore, the view of the national diamond theory is also applicable to the export industry of higher education participating in the competitive international market. It helps provide a broader perspective for the study of higher education export industry, in the sense that the research carried out should not be limited to the internal factors of colleges and universities; it also needs to pay attention to the interaction between colleges and their external settings, such as external demand, related and supporting institutions and so on.

The main research objective of this paper is the competitiveness of education export by local colleges and universities, and as a result, the various elements defined in Porter's "National Diamond Model" need to be revised to suit the present need. These modified factors are shown in Table 1. 


\section{ENTREPRENEURSHIP AND SUSTAINABILITY ISSUES}

ISSN 2345-0282 (online) http://jssidoi.org/jesi/

2020 Volume 7 Number 3 (March)

http://doi.org/10.9770/jesi.2020.7.3(28)

Table 1. Analysis elements in Porter's National Diamond Model

\begin{tabular}{|c|c|}
\hline & Analysis element \\
\hline Production conditions & $\begin{array}{c}\text { The geographical location of colleges and universities, investment in infrastructure and information } \\
\text { automation, investment in human resources, etc. }\end{array}$ \\
\hline Demand conditions & $\begin{array}{l}\text { In a certain period of time, the requirements on the number, quality, and structure of educational } \\
\text { service providers by all sectors of the national economy and society. }\end{array}$ \\
\hline $\begin{array}{l}\text { Related and supporting } \\
\text { industries }\end{array}$ & The international competitiveness in service trade of the education and related industries. \\
\hline $\begin{array}{l}\text { Strategy and competitor } \\
\text { analysis }\end{array}$ & $\begin{array}{l}\text { The orientation of the development strategy on the internationalization of colleges and universities, } \\
\text { and the degree of mutual competition among colleges and universities, etc. }\end{array}$ \\
\hline Opportunity analysis & $\begin{array}{l}\text { An unplanned, chance happening event that affected the development of education export in a } \\
\text { country. }\end{array}$ \\
\hline $\begin{array}{c}\text { Analysis of government } \\
\text { elements }\end{array}$ & $\begin{array}{l}\text { Promoting and standardizing the relevant policies on education export, the investment in the urban } \\
\text { infrastructure and the education export support industry, and the financing of educational export in } \\
\text { colleges and universities, etc. }\end{array}$ \\
\hline
\end{tabular}

Source: Michael Porter (2008). Competitive Strategy: Techniques for analyzing industries and competitors: with a new introduction.

\subsubsection{The regression model theory}

Regression analysis is an effective way to explore the relationship among independent variables. Multivariate regression assumes a multivariable causal model (such as in "X1, X2, and X3 resulted in Y"), which can not only explain whether multiple variables are dependent is relevant and how much correlation, but also can test the direction of the association. That is, the direction of the causal model itself, and the extent to which multiple independent arguments significantly affect a single variable. With a SPSS multivariate regression, with the continuous introduction of explanatory variables, the explanatory coefficients of some explanatory variables that have entered the regression equation are no longer significant; and the gradual screening strategy in multivariate regression can judge whether there are explanatory variables that can be eliminated, thus improving the accuracy of prediction by the model.

\subsection{Main research objectives and methods}

\subsubsection{The main objective of the current research}

The ultimate aim of this study is to help improve the international sustainable competitiveness of China's education exports. The research first comprehensively clarified the history, present situation, and issues of the education export of local colleges and universities in China. The study then analyzed the factors affecting the international sustainable competitiveness of the education export of these institutions, based on Porter's National Diamond model. It then collected relevant data and established the underlying regression model to find the core elements that affect China's international sustainable competitiveness in the educational exports. And finally, it put forward an effective way to enhance China's international sustainable competitiveness in the education service market.

\subsubsection{The main methods of research.}

This thesis adopts the approach of combining the qualitative description with relevant quantitative analysis and emphasizing both the theoretical and empirical research.

(1) Literature Analysis Method

Consult the research literature on competitive (the national diamond theory), regression analysis theory, and make material preparation for comprehensive analysis such as theoretical analysis and literature review.

(2) Empirical Analysis method

Collect and analyze data through statistical yearbook and related websites, carry out realistic empirical analysis, convert the data into meanful information, and then draw conclusions. 


\section{ENTREPRENEURSHIP AND SUSTAINABILITY ISSUES}

ISSN 2345-0282 (online) http://jssidoi.org/jesi/

2020 Volume 7 Number 3 (March)

http://doi.org/10.9770/jesi.2020.7.3(28)

\section{Results and discussion}

\subsection{Theoretical analysis}

\subsubsection{History of educational export of local colleges and universities in China}

Most of the initial education export originated from international academic exchanges, education abroad, and international education assistance. In the early days after the founding of the country, China was in a period of economic recovery; facing the international situation then and in order to strengthen exchanges and cooperation among socialist countries, China and Poland, Czechoslovakia, Romania, Hungary, Bulgaria started exchanging international students. The 33 students from the 5 afore-mentioned countries who studied in China in 1950 opened the way of export of non-profit education in China. With the development of the relationship between China and neighboring countries, the Soviet Union, Vietnam, and other newly independent countries in Asia, Latin America, and Africa have come to China to study. According to statistics, China has received and trained 7,239 international students from 68 countries (1950-1966). As a result of the outbreak of the Cultural Revolution, the higher education system was completely suspended and subsequently the higher education exports were fully stopped and were not restored until early 1973. So far, China's education export is still guided by the national diplomatic strategy and dominated by the subordinate colleges and universities. There is hardly any trade in educational service. However, this early experience served well for China's local colleges and universities in the preparation for the development of education export.

Since the reform and opening, and with the substantial improvement of China's education level, international cultural and educational exchanges have been strengthened. According to statistics, from 1973 through 1989, China accepted a total of 15,978 scholarship students and more than 20,000 self-sponsored students from 129 countries. In a sense, this is the beginning of China's modern-day education export.

Entering the 1990s, with the Soviet influence and the world's multi-polarity political situations, China's international status is rising rapidly, providing a good external environment for education exports. At the same time, the national policy of relegating the right to recruit international students to local authorities has pushed the local colleges and universities to become the main body of higher education exports. China's education export business has seen a breakthrough. During the period 1990-1999, the total number of higher education exports in China were 6.1 times that from 1950-1989.

Local colleges and universities began to occupy a prominent place in higher education exports.

Since entering the new century, education export has gradually evolved into a new type of international service trade industry, and the competition in international education market is becoming ever fierce. And the form of export is no longer confined to the original international student recruitment; it has expanded to include activities involved in running institutions overseas, and to provide cross-border distance learning.

\subsubsection{Current situation of education export in local colleges and universities in China The import and export imbalance of higher education}

As China's higher education exports started late and there were many obstacles, China's education exports are still much lower than education imports, and the deficit remains grim (see Figure 1.) In addition, the deficits figures indicated a widening trend. 
ENTREPRENEURSHIP AND SUSTAINABILITY ISSUES

ISSN 2345-0282 (online) http://jssidoi.org/jesi/

2020 Volume 7 Number 3 (March)

http://doi.org/10.9770/jesi.2020.7.3(28)

Figure 1. The change of China's education export deficit (2006-2015)

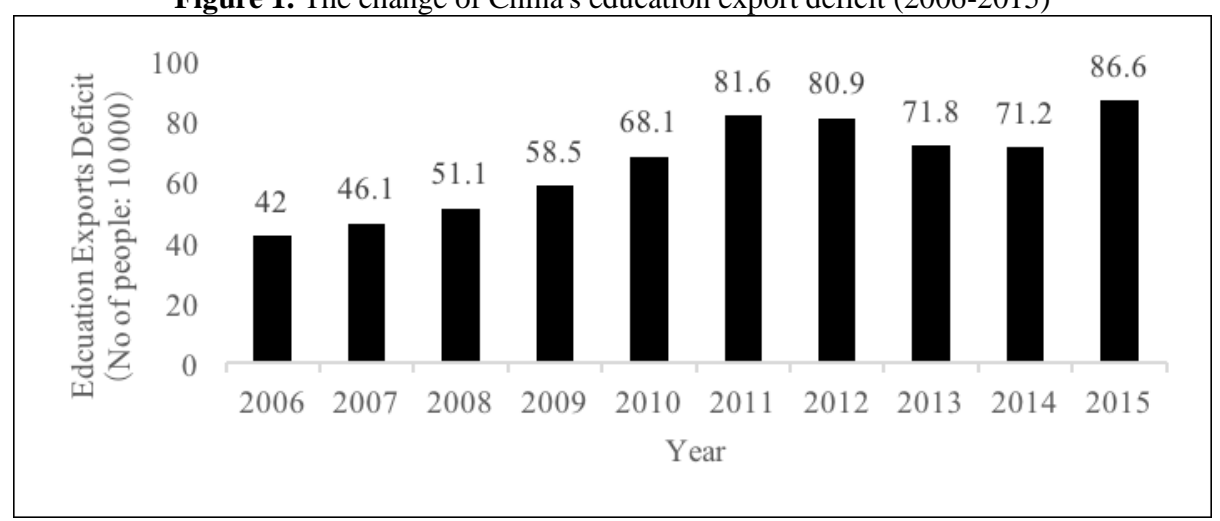

Source: Base on the statistics on inbound international students and overseas Chinese students from 2006-2015 by the Chinese Ministry of Education

\subsubsection{The slowdown of the growth of education exports}

Since 1990, China has seen rapid development of inbound international students. This is especially true since the introduction of the "Road and Belt Initiative" when the central government and the society in general have place increased attention on foreign students coming to study in China. And the number of students coming here to enroll in local colleges and universities showed a good growth trend. However, this growth rate has slowed since 2010, and even began to fall below the 10\% level, beginning in 2013 (see Figure 2), according to statistics from the Ministry of Education.

Figure 2. Growth in the number of international students coming to China (2006-2015)

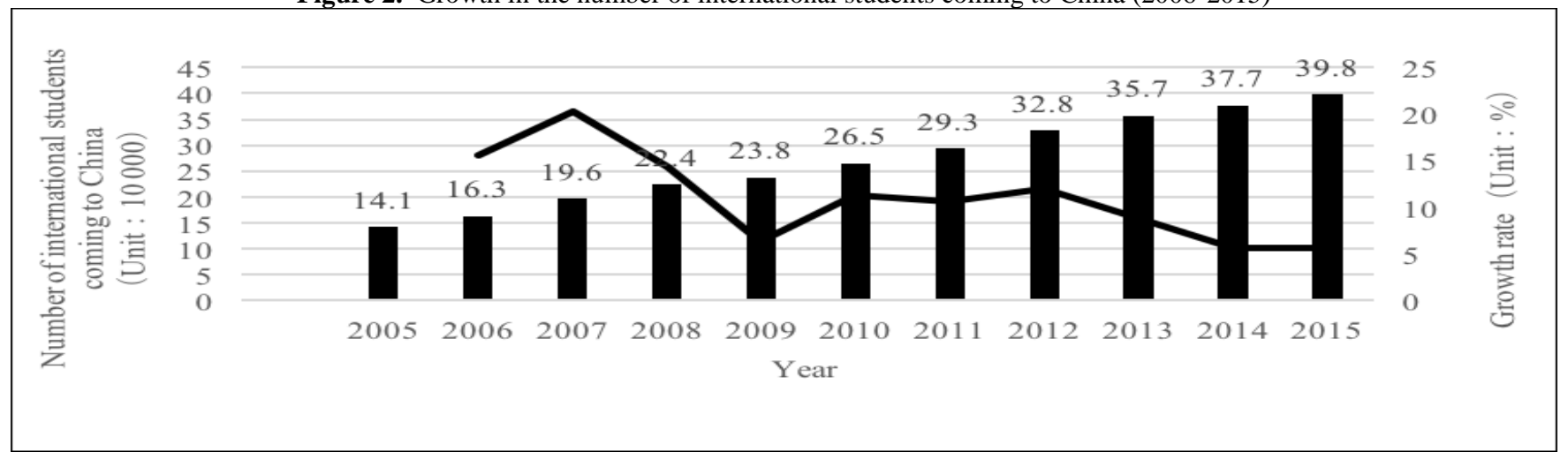

Source: Base on the statistics on inbound international students and overseas Chinese students from 2006-2015 by the Chinese Ministry of Education

The level of education export is lower than that of other countries, and local colleges and universities ranked lower than subordinated colleges

According to statistics, by the end of 2016, the average number of foreign students in each local university was 358.07, representing $2.06 \%$ of the total enrollment. This average is well below the traditional hotspot countries such as the United States and Britain, and the emerging destinations such as New Zealand and Australia. In addition, the number and percentage of international students enrolled in local colleges and universities are significantly lower than that of the subordinate colleges and universities (see Table 2). 
ENTREPRENEURSHIP AND SUSTAINABILITY ISSUES

ISSN 2345-0282 (online) http://jssidoi.org/jesi/

2020 Volume 7 Number 3 (March)

http://doi.org/10.9770/jesi.2020.7.3(28)

Table 2. Scale of various types of international students coming to China

\begin{tabular}{|c|c|c|c|}
\hline & & Average & $\begin{array}{l}\text { Std } \\
\text { Deviation }\end{array}$ \\
\hline \multirow[t]{2}{*}{ Number of international students coming to China } & Subordinate colleges \& universities & 1471.11 & 1495.795 \\
\hline & Local colleges \& universities & 177.04 & 409.358 \\
\hline \multirow{2}{*}{$\begin{array}{c}\text { International students as a proportion of the total } \\
\text { number of students }\end{array}$} & Subordinate colleges \& universities & $6.58 \%$ & 17.902 \\
\hline & Local colleges \& universities & $1.32 \%$ & 7.407 \\
\hline
\end{tabular}

Source: Based on a series of survey studies of the international development of higher education in China (www.survey.ceaie.edu.cn)

In addition, to further distinguish between different types of colleges and universities (subordinate universities or local colleges and universities), in 2016, the average level of international students in China with academic accreditation was 699.16 for subordinate colleges and universities, and that number for local colleges and universities was only 85.79; the average number of non-academic students in subordinate colleges and universities was 771.95, whereas for local colleges and universities, the number was 91.24. In other words, local colleges and universities lagged far behind the subordinate colleges and universities in the training of both the academic accreditation and non-academic students.

\section{The level of education still needs to be further improved}

At present, the educational level of students coming to China can be divided into academic accreditation and nonacademic education: Academic accreditation includes the undergraduate and postgraduate education, while nonacademic education is mainly for short-term training. Since 1990, both academic accreditation and non-academic education have shown a steady growth trend. However, as of 2016, when compared with other developed countries, the proportion of international academic accreditation students in China is still low (47.63\%). The number was relatively higher for non-academic students, especially in the short-term language learning. In addition, the proportion of students coming to China with higher education level also indicated a big gap when compared with Europe and the United States. According to the OECD's "Education at a Glance", in 2015, for Switzerland, Britain, the US, Australia, Sweden and other countries, the "proportion of international students studying for the doctoral degree" was 54\%, 43\%, 38\%, 34\% and 34\%, respectively; while the proportion of international students studying for master's and doctoral degrees in China was only $7.37 \%$. This shows that although the academic structure for international student education in China is gradually optimized, there is still a big gap when compared with other developed countries. This requires that local colleges and universities to further enhance the internationalization level of disciplines and specialties and adjust the level and structure of academic qualifications.

\subsection{Empirical tests based on the regression analysis \\ 4.2.1 Variable selections}

In order to quantitatively analyze the factors affecting the export sustainable competitiveness of local colleges and universities in China, we selected the number of educational exports ** of local colleges and universities in China as the dependent variable, and selected certain indexes as independent variables, based on the six factors defined in the Porter's National Diamond model. We performed the statistical analysis and the relationship between the respective independent variables and the dependent variables is presented. The independent variables are as follows:

1. On production conditions: The "average of funds invested per student" (X1), and the "teacher-to-student" ratio (X2) are proposed in the study. Their expected regression coefficients are positive.

2. On the demand conditions: The "enrolment rate of higher education" (X3), and "per capita GDP" (X4) necessary to reflects domestic demand are used here in this category. Both of the expected regression coefficients are positive. 
3. On related and supporting industries: The "comprehensive trade sustainable competitiveness index of service trade" (X5), and "urban population rate" (X6) are suggested. The expected regression coefficients for both variables are positive.

4. On strategy and competitors: The "proportion of scholarship students to local Chinese students" (X7), and the "number of institutions that have international student enrollment" (X8) are the two indicators used in the analysis. The expected regression coefficients are positive.

5. On elements of government: The "proportion of higher education in the GDP" (X9) is the indicator for this category. The expected regression coefficient is positive.

6. The aspects of opportunity: The use of a simulation (virtual) variable to represent the chance happening of certain events. For instance, this variable was set to 1 for the occurrence of the following events: when the new standard of fees for self-funded international students was introduced in 1998, China's accession to the WTO in 2001, the outbreak of SARS in 2003, the world financial crisis in 2008, and the H1N1 outbreak in 2009. The value was set to 0 for other years.

\subsubsection{The regression analysis}

Suppose the multivariate linear regression model is represented as:

$\mathrm{Y}_{\mathrm{i}}=\beta_{0}+\beta_{1} \mathrm{X} 1_{\mathrm{i}}+\beta_{2} \mathrm{X} 2_{\mathrm{i}}+\beta_{3} \mathrm{X} 3_{\mathrm{i}}+\beta_{4} \mathrm{X} 4_{\mathrm{i}}+\beta_{5} \mathrm{X} 5_{\mathrm{i}}+\beta_{6} \mathrm{X} 6_{\mathrm{i}}+\beta_{7} \mathrm{X} 7_{\mathrm{i}}+\beta_{8} \mathrm{X} 8_{\mathrm{i}}+\beta_{9} \mathrm{X} 9_{\mathrm{i}}+\beta_{10} \mathrm{X} 10_{\mathrm{i}}(\mathrm{i}=1,2, \ldots, 20)$

The SPSS software was then used to perform a multivariate linear regression analysis (entry method) using the original data collected and the results are presented in Table 3. It is evident that most of the independent variables showed a statistical significance greater than 0.05 ; thus, it is necessary to consider the possibilities of the Multicollinearity effects and take stepwise regression again to delete the variables unnecessary automatically by using SPSS.

Table 3. Coefficients

\begin{tabular}{|c|c|c|c|c|c|c|}
\hline \multicolumn{2}{|c|}{ Model } & \multicolumn{2}{|c|}{ Non-standardized coefficient } & \multirow{2}{*}{$\begin{array}{c}\begin{array}{c}\text { Standard } \\
\text { coefficient }\end{array} \\
\text { Trial Edition } \\
\end{array}$} & \multirow[t]{2}{*}{$\mathbf{t}$} & \multirow[t]{2}{*}{ Sig. } \\
\hline & & $\mathbf{B}$ & Standard error & & & \\
\hline \multirow[t]{11}{*}{1} & Constant & -108642.996 & 111689.750 & & -.973 & .356 \\
\hline & $\mathrm{X} 1$ & -3.672 & 2.188 & -.181 & $\begin{array}{l}-1.678 \\
\end{array}$ & .128 \\
\hline & $\mathrm{X} 2$ & 972.622 & 1613.267 & .016 & .603 & .561 \\
\hline & $\mathrm{X} 3$ & 2556.441 & 2010.674 & .198 & 1.271 & .235 \\
\hline & $\mathrm{X} 4$ & 4.341 & 1.570 & .534 & 2.765 & .022 \\
\hline & $\mathrm{X} 5$ & -703.061 & 491.072 & -.043 & -1.432 & .186 \\
\hline & $\mathrm{X6}$ & -1269.377 & 5137.894 & -.076 & -.247 & .810 \\
\hline & $\mathrm{X7}$ & 2124.239 & 3229.160 & .035 & .658 & .527 \\
\hline & $\mathrm{X} 8$ & 290.194 & 84.030 & .382 & 3.453 & .007 \\
\hline & $\mathrm{X} 9$ & 63770.982 & 66221.972 & .114 & .963 & .361 \\
\hline & $\mathrm{X} 10$ & -3088.029 & 3333.603 & -.010 & -.926 & .378 \\
\hline
\end{tabular}

After the progressive adjustments, the results are shown in Tables 4 \& 5. (

Table 4. Model Summary

\begin{tabular}{c|c|c|c|c}
\hline \hline Model & R & R Square & Adjusted R Square & Error in standard estimation \\
\hline 1 & $.996^{\mathrm{a}}$ & .991 & .991 & 12672.69672 \\
\hline 2 & $.998^{\mathrm{b}}$ & .995 & .995 & 9803.53978 \\
\hline 3 & $.999^{\mathrm{c}}$ & .999 & .999 & 5068.40147 \\
\hline \hline
\end{tabular}


ENTREPRENEURSHIP AND SUSTAINABILITY ISSUES

ISSN 2345-0282 (online) http://jssidoi.org/jesi/

2020 Volume 7 Number 3 (March)

http://doi.org/10.9770/jesi.2020.7.3(28)

Table 5. Coefficients*

\begin{tabular}{|c|c|c|c|c|c|c|}
\hline \multicolumn{2}{|r|}{ Model } & \multicolumn{2}{|c|}{ Non-standardized coefficient } & \multirow{2}{*}{$\begin{array}{c}\begin{array}{c}\text { Standard } \\
\text { coefficient }\end{array} \\
\text { Trial Edition } \\
\end{array}$} & \multirow[t]{2}{*}{$\mathbf{t}$} & \multirow[t]{2}{*}{ Sig. } \\
\hline & & B & Standard error & & & \\
\hline \multirow[t]{2}{*}{1} & Constant & -223241.268 & 9432.910 & & -23.666 & .000 \\
\hline & $\begin{array}{l}\text { number of institutions that have } \\
\text { international student enrollment }\end{array}$ & 756.973 & 16.720 & .996 & 45.273 & .000 \\
\hline \multirow[t]{3}{*}{2} & Constant & -326979.432 & 29599.778 & & -11.047 & .000 \\
\hline & $\begin{array}{l}\text { number of institutions that have } \\
\text { international student enrollment }\end{array}$ & 535.853 & 62.498 & .705 & 8.574 & .000 \\
\hline & urban population rate & 4951.650 & 1369.254 & .297 & 3.616 & .002 \\
\hline \multirow[t]{4}{*}{3} & Constant & -259456.107 & 18164.880 & & -14.283 & .000 \\
\hline & $\begin{array}{l}\text { number of institutions that have } \\
\text { international student enrollment }\end{array}$ & 257.108 & 51.733 & .338 & 4.970 & .000 \\
\hline & urban population rate & 5272.456 & 709.426 & .317 & 7.432 & .000 \\
\hline & Per capita GDP & 2.869 & .416 & .353 & 6.899 & .000 \\
\hline
\end{tabular}

*Note: Dependent variable- number of educational exports

From the results of Table 4, it is clear that the fitting of the final model is very superior, with all the coefficients registering a value greater than 0.9. From the outcome in Table 5, it is evident that the significance of the three independent variables of X8: the "number of institutions that have international student enrollment", X6: the "urban population rate", and X4: the "per capita GDP" is less than 0.05, meaning the due variable, the "number of educational exports" is affected significantly by these three independent variables. The expression equation of the final model is:

$\mathrm{Yi}=2.869 \mathrm{X} 4 \mathrm{i}+5272.456 \mathrm{X} 6 \mathrm{i}+257.108 \mathrm{X} 8 \mathrm{i}-259456.107(\mathrm{i}=1,2, \ldots, 20)$

\section{Conclusions}

\subsection{Empirical Conclusion}

From the results of the empirical test, the factors that have a significant impact on the number of education exports by local colleges and universities in China are the "number of institutions that have international student enrollment", the "urban population rate", and the "per capita GDP". The remaining seven factors (as defined in section 4.2.1) have little or no impact. One possible reason could be that the selected variables are not a good proxy for the relevant factors. Another plausible explanation may be that the statistical complexity hinders the embodiment of the variables. Although some of the variables do not have a significant impact, they were still incorporated in the following analysis, per the definition presented in Table 4.

First, on the production conditions, the two indicators of the "average of funds invested per student" (X1), and the "teacher-to-student" ratio (X2) did have a positive but insignificant correlation to the due variable - the local university education exports.

Second, on the demand conditions, the "per capita GDP" showed a significant impact on the number of education exports. From the regression results, the coefficient is 2.869 , indicating that when other variables remain unchanged, for a $1 \%$ change of the "per capita GDP", the number of local university education exports will change by $2.869 \%$. The implication is that the education exports of local colleges and universities are directly proportional to the living standards of the people. Although the "enrolment rate of higher education" factor is not statistically significant, the regression results indicated that for each $1 \%$ change in this indicator, exports will produce a certain amount of change in the same direction. The implication is that, to some extent, the increase in the enrolment rate of higher education is helpful for the improved the export of education. 


\section{ENTREPRENEURSHIP AND SUSTAINABILITY ISSUES}

ISSN 2345-0282 (online) http://jssidoi.org/jesi/

2020 Volume 7 Number 3 (March)

http://doi.org/10.9770/jesi.2020.7.3(28)

Third, on related and supporting industries, the "urban population rate" has a significant and positive impact on the number of local university education exports. That is, the higher the urban population rate, the higher the number of education exports by local colleges and universities. The inherent reason is that urbanization will improve (i) the living standards of residents, (ii) the city's infrastructure and environment, and (iv) the globalization level of the city. These ultimately lead to enhanced export of education services by local colleges and universities. The "comprehensive trade sustainable competitiveness index of service trade" has no significant impact on the due variable and is negatively correlated. This may be due to the fact that the index in the data is too broad in scope; in addition, the current trade in services is still in its infancy and not in a position to provide adequate support for the improvement of education exports.

Fourth, on strategy and competitors, the "number of institutions that have international student enrollment" showed significant impact on the education exports. Judging from the regression results, its coefficient is 257.108 , meaning that for every unit of increase in the input variable, there would be a corresponding increase of 257.08 unit in the education exports. This clearly reflects that the market for international students is not saturated at present, and the competition among institutions for international student enrollment is not very fierce. An increase in enrollment institutions has instead increased the number of education exports. The variable of "proportion of scholarship students to local Chinese students" has a positive effect on the due variable, but the effect is not significant.

Fifth, on the elements of government, the "proportion of higher education in the GDP" has a positive impact on the number of education exports, but the impact is not significant. This shows that the investment made in local colleges and universities has brought a better teaching/learning environment for the institutions and provided for an important support needed for the all-purpose development of schools; however, its impact on local higher education exports is not satisfactory, statistically speaking. The reason could be that the original data of this study is not enough, or it may also indicate that the above educational investment generated only limited resources for the international students.

Sixth, on the aspect of opportunity, the impact of the simulation variable is not significant. Based on the trend of the due variable, except in 2003 where there has been a significant decline in the number of education exports, there have been no notable changes due to the introduction of this virtual parameter.

\subsection{The means for improving the sustainable competitiveness in education exports}

\section{Firstly, to improve the domestic demand structure and upgrade the level of external demand}

With the improvement of China's economic level and the expansion of the enrollment process in colleges and universities, the gross enrollment rate is growing rapidly. However, due to the rising threshold in the area of education that was imposed by the marketplace of employment and the imbalance in supply and demand for higher education, the unbalanced structure for domestic demand is formed as a result. Students prefer to attend the "985", "211", or other subordinate colleges and universities, and local colleges and universities are left out in the process. The central government should provide policy support for local colleges and universities, change the general public's perception about these institutions, and improve the employment opportunities for their graduates. These arrangements would attract more students to consider and enroll in the local colleges and universities, and hence gradually transform into a balanced cycle.

In addition to the quality of the desired educational products, international students will also focus on the economic conditions, living environment and employment opportunities of the country; this is especially true for international students coming to China. From the perspective of the historical development process evident in developed countries, most of them offers a comfortable environment for living, studying and working, and has a perfect support system for international students. China should also try to offer the similar as soon as possible. 


\section{ENTREPRENEURSHIP AND SUSTAINABILITY ISSUES}

ISSN 2345-0282 (online) http://jssidoi.org/jesi/

2020 Volume 7 Number 3 (March)

http://doi.org/10.9770/jesi.2020.7.3(28)

First of all, it is necessary to improve the basic security system, such as medical care and housing, so that international students can integrate more quickly and comfortably into the local communities. Secondly, to expand the scope of scholarships offered, to expand the channels for scholarship fund raising, and to set up educational trust funds in order to attract outstanding students. In addition, the policy restrictions on internships and employment for international students need to be revised. On the one hand, we can properly reduce the financial burden on these international students, and on the one hand, they can better understand China and easily integrate into local communities. And finally, local colleges and universities should to try identifying a correct orientation, to attach more importance to improving the education management system, and to improve the level of education services.

\section{Secondly, to speed up the process of urbanization and perfect the educational service system}

In the long run, the improvement of the comprehensive urban level is the foundation of educational development and the only way for a country to achieve sustainable development. In the process of speeding up the urbanization process and getting the positive effects out of urbanization, the government should formulate the corresponding export strategy on trade in education services and accelerate the pace of the export of trade in education services. From the short term, it is more realistic to improve the education service system for international students; this system includes the establishing and perfecting of the mutual recognition of academic qualifications, simplifying the enrollment procedure, shortening the visa process, and promoting the formation of agencies to serve as an intermediary. These activities are of great significance to further expand the education exports by local colleges and universities.

\section{Thirdly, to implement adjustment measures for the strategic structure of education exports}

There is a need to improve the administrative management system of the higher education. It is necessary endow local colleges and universities with the autonomy to operate their schools, and to vigorously increase the number of college student's enrollment. The policy also needs to allow more local colleges and universities to participate in the recruitment of international students, and to avoid the political tilting in favor of the subordinate colleges and universities. This levelled playing field would help promote more local colleges and universities to participate in competition.

It is essential to establish and perfect the educational quality and supervision mechanism for international students. From the practical experience gained by the developed countries in trade in higher education services, the more successful systems always have a relatively independent quality assurance and audit support program. In view of this, our country should gradually remove the influence of formalism and bureaucracy and establish a credible third-party education quality assurance program for international students.

\section{References}

David Ricardo. 2014. On the Principles of Political Economy, and Taxation. Nanjing: Yinlin Press. Department of Development Planning, Ministry of Education, People's Republic of China. 2016. Chinese Education Statistics Yearbook. Beijing: China Statistics Press.

Department of Development Planning, Ministry of Education, People's Republic of China. 2016. Chinese Education Statistics Yearbook. Beijing: China Statistics Press.

Feng, W., Yixiao, H. 2014. Comparison and related orientation of international competitiveness of education service trade. Reform, 2014(7), 116-125. Retrieved from http://kns.cnki.net

Girdzijauskaite, E., Radzeviciene, A., Jakubavicius, A. 2019. Impact of international branch campus KPIs on the university competitiveness: FARE method. Insights into Regional Development, 1(2), 171-180. https://doi.org/10.9770/ird.2019.1.2(7) 


\section{ENTREPRENEURSHIP AND SUSTAINABILITY ISSUES}

ISSN 2345-0282 (online) http://jssidoi.org/jesi/

2020 Volume 7 Number 3 (March)

http://doi.org/10.9770/jesi.2020.7.3(28)

Guiyong, Z. 2007. A Comparative Study of International Competitiveness of Service Trade among South Korea, Japan and China (Unpublished doctor dissertation). East China Normal University.

Havierniková, K.; Kordoš, M. 2019. Selected risks perceived by SMEs related to sustainable entrepreneurship in case of engagement into cluster cooperation, Entrepreneurship and Sustainability Issues 6(4): 1680-1693. http://doi.org/10.9770/jesi.2019.6.4(9)

Haviernikova, K.; Klucka, J. 2019. The risks in the case of cluster cooperation and ways of their prevention: as seen by SMEs entrepreneurs. AD ALTA - Journal of interdisciplinary research Volume 9: Issue 1: 114-119

Jie, S. 2012. A study on the international competitiveness of Chinese higher education service trade (Unpublished master dissertation). Capital University of Economic and Business.

Knight, J. 2002. Trade Creep: Implications of GATS for Higher Education Policy, Physics \& Chemistry of the Earth Parts A/b/c, 36(9), 455458.

Levicky, M. et.al. 2019. Convergence tendencies in the conditions of regions of the Slovak Republic. In Klímová, V., Žítek, V. (eds.) 22nd International Colloquium on Regional Sciences. Conference Proceedings. Brno: Masaryk University Press, 2019. pp. 1-5. ISBN 978-80210-9268-6. http://dx.doi.org/10.5817/CZ.MUNI.P210-9268-2019-2

Niu, J. 2016. Empirical Research on the Influencing Factors of the international competitiveness on China's Higher Education Service Trade, Economic Outlook the Bohai Sea, 2017(9), 33-38. http://dx.doi.org/10.3969/j.issn.1004-9754.2016.09.009

OECD iLibrary. 2017. Education at a Glance. Retrieved September 12 ${ }^{\text {th }}$, 2017, Retrived from http://www.oecd-ilibrary.org.

Porter, M. 2014. Competitive Strategy: Techniques for analyzing industries and competitors: with a new introduction. Beijing: Citic Press.

Report on China's Foreign Trade (2017). Retrived from http://www.mofcom.gov.cn

Research Report of Education Internationalization. 2015. Retrived from http://www.suvey.ceaie.edu.cn

Ricardo, D. 2014. On the Principles of Political Economy, and Taxation. Nanjing: Yinlin Press.

Sijun, W., Liangliang, Q. 2016. Development Strategy of Higher Education Service Trade under the background of "One Belt \& Road", China Journal of Commerce, 2016(7), 123-125. Retrived from http://kns.cnki.net

Smith, A. 2014. The Wealth of Nations. Beijing: The Commercial Press.

Statistical Reports on Education Development. 2017. Retrieved from http://www.moe.gov.cn

Statistical Yearbook of P.R.C. 2018. Retrieved from http://www.stats.gov.cn

Study in China. 2010. Retrived from http://www.gov.cn

Wei, X. 2011. Data analysis based on SPSS, Beijing: Renmin University of Chinese Press.

Weike, S. 2013. Research on Higher Education Service Trade of China-ASEAN: Based on the perspective of New Institutional Economics (Unpublished master dissertation). Guangxi University.

Xi, C. 2015. Analysis of the Competitiveness \& the Factors of China Higher Education Service Exports (Unpublished master dissertation). China Youth University of Political Studies.

Xiang, Z. 2016. Research on the sustainable competitive advantage of higher education in China under the background of internationalization. Theory and Practice of Contemporary Education, 8(4), 114-116. Retrieved from http://kns.cnki.net

Xin, L. 2007. Research on the Influencing Factors of the international competitiveness on China's Higher Education Service Trade (Unpublished master dissertation). Hunan Univerity.

Xin, L. 2013. Research on Competitive Factors of Higher Education Service Trade in China (Unpublished master dissertation). Central South University. Retrieved from http://kns.cnki.net 


\section{ENTREPRENEURSHIP AND SUSTAINABILITY ISSUES}

ISSN 2345-0282 (online) http://jssidoi.org/jesi/

2020 Volume 7 Number 3 (March)

http://doi.org/10.9770/jesi.2020.7.3(28)

\section{Acknowledgements}

The paper is the output of an international scientific project IGA no. 2/2018 - M „Problems and Suggestions - Comparison of Commercial Enviroment between China - Slovakia and Facilitation of Trade and Investment". (Funder: VSEMvs IGA VSEMvs, i.e. School of Economics and Management in Public Administration) and scienfitic project code: Y201942732 "Research on the path of increasing the abilities of Higher Education Exports of Zhejiang under Anti-Globalization" (Funder: Education Deparment of Zhejiang, PRC, project classification - General Scientific Research Project)

Yingfei YANG is PhD. Candidate in International Business, Sejong University, Seoul, South Korea. Meanwhile, she is the Deputy Director of Foreign Affairs Office of Ningbo University of Finance \& Economics, PRC. Research interests: International Education, Service Trade, Sustainability development of international education.

ORCID ID: https://orcid.org/0000-0001-5989-7447

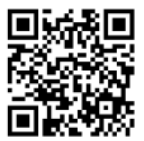

Michal FABUS PhD. in International Economics Relations, obtained at University of Economics in Bratislava, Vice-rector for Foreign Affairs, Head of Department of Economics and Finance, School of Economics and Management in Public Administration in Bratislava (VSEMvs), Slovakia.

ORCID ID: orcid.org/0000-0002-3792-179X

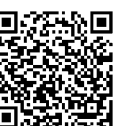

BAE KI-HYUNG is Doctor of Economics, Graduated from Sejong University in 1992. Worked in Sejong University. His research interests include cultural economics, cultural content industry and applied microeconomics.

ORCID ID: https://orcid.org/0000-0001-5067-0684

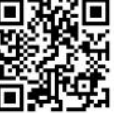

ZHANG MENGZE is Ph.D Candidate in the Department of Economics and Trade, Sejong University, Seoul, South Korea. His research interests include logistics and industrial economy.

ORCID ID: https://orcid.org/0000-0003-1370-0391

Copyright (C) 2020 by author(s) and VsI Entrepreneurship and Sustainability Center

This work is licensed under the Creative Commons Attribution International License (CC BY).

http://creativecommons.org/licenses/by/4.0/

(c) (†) Open Access 